\title{
The Importance of Resilience in the Women, Peace and Security Agenda Particularly during the Covid- 19 Pandemic
}

\section{María Julia Moreyra}

PeaceWomen Across the Globe, http://www.1000peacewomen.org/

\begin{abstract}
Women have taught different ways of resilience through their actions in their communities. They have developed resilience and leadership. 2020 is an outstanding year regarding gender equality and women's empowerment, as it marks the anniversary of unprecedented policy commitments and practical action frameworks. COVID-19 has dramatically changed the lives of women, girls, and adolescents all over the world. Many women in charge of their communities are at the front line protecting their people and are the backbone of society's resilience. Even though most of them are affected by the virus, they go on working hard, trying to do their best for their people. It is pivotal to apply a feminist lens into foreign policies, and when implementing the Women, Peace and Security Agenda, it is extremely important to take into account that women are key actors in building resilient democratic societies.
\end{abstract}

Keywords: resilience, refugee women, displaced women, Covid-19, UNSCR 1325 , actors of change, gender equality, women's empowerment, crisis.

To my mother, the best example of resilience

\section{Introduction}

The present article deals with an important topic, particularly facing humanity as a consequence of COVID-19. Resilience is pivotal in the Women, Peace and Security Agenda, which celebrates its 20th anniversary this year. As will be developed in the article, women are at the front line, protecting their communities from the threat of the pandemic. Throughout six sections, the main contents of 
the agenda will be analyzed, emphasizing women's resilience to which Resolution 1325 and subsequent resolutions are directed.

It is of great importance to analyze the evolution of the concept of resilience to know what lessons have been learned and how good practices are applied in the implementation of the concept of resilience in this complex moment. Special mention will be made of two groups of women, refugees, and displaced women, who are included in Resolution 1325 and who have demonstrated throughout their hard living conditions to be resilient. Finally, we will address the resilience developed by women worldwide in the wake of the pandemic and how they prioritize their communities at all times.

\section{Women, Peace, and Security}

Unanimously adopted on October 31, 2000, Resolution 1325 is the first ever resolution passed by the United Nations Security Council acknowledging the need for and contributions of half the world's population-women-to international peace and security.

Women and men experience violent conflicts as gross human tragedies. But the roles, experiences, needs, and interests of women, girls, men, and boys are very different. Women are more severely affected by sexual abuse and domestic violence, displacement, and social discrimination, and they need to be very resilient to sustain themselves and their communities. They carry heavy burdens.

PeaceWomen Across the Globe (PWAG), a Swiss organization that came into existence after the nomination of 1000 women to the Nobel Peace Prize in 2005, recognized 5 Ps for peace taken from the Resolution:

- Participation: greater inclusion of women in peacebuilding

- Prevention of conflict and gender-based violence

- Protection of the rights and needs of women and girls during and after armed conflicts

- Peacekeeping and Peacebuilding: gender mainstreaming in all activities and phases. ${ }^{1}$

The most important aspect of UNSCR 1325 is that it recognizes thousands of peace women across the globe as "actors of change." When women are better, whole communities benefit.

Women from the Balkans, Burundi, Cote d' Ivoire, Democratic Republic of Congo, Guinea-Bissau, Haiti, and Iraq, among others, who held meetings with representatives of the General Secretary of the United Nations on the occasion of the 10th anniversary of UNSCR 1325, showed great resilience before the obstacles and challenges they faced.

In its last paragraph, UNSCR 1325 established that the Security Council "Decides to remain actively seized of the matter." Following this commitment, the

1 No Women - No Peace: 10 Years UN Resolution 1325 (Switzerland: PeaceWomen Across the Globe, 2010), 2. 
Security Council adopted these Resolutions: 1820 (2008); 1888 (2009); 1889 (2009); 1960 (2010); 2106 (2013); 2242 (2015); 2250 (2015). UNSCR 1820 condemns the use of sexual violence as a tool of war and declares that "rape and other forms of sexual violence can constitute war crimes, crimes against humanity or a constitutive act with respect to genocide." Through UNSCR 1888, the Security Council decided to specifically mandate peacekeeping missions to protect women and children from rampant sexual violence during armed conflict, as it requested the Secretary-General to appoint a special representative to coordinate a range of mechanisms to fight crime. In UNSCR 1889, the Security Council called for a wide range of measures to strengthen women's participation at all stages of peace processes, focusing on the period after peace agreements have been reached, as it began an intensive day-long discussion on the topic. In UNSCR 1960, the Council requested information on parties suspected of patterns of sexual violence during armed conflict to be made available to it. UNSCR 2106 reiterates that all actors, including not only the Security Council and parties to armed conflict but all member states and United Nations entities, must do more to implement previous mandates and combat impunity for these crimes. With UNSCR 2242, the Council decided to integrate women, peace, and security concerns across all country-specific situations on its agenda. In UNSCR 2250, the Security Council urged member states to consider ways to increase the inclusive representation of youth in decision-making at all levels in local, national, regional and international institutions and mechanisms for the prevention and resolution of conflict, countering violent extremism, other activities conducive to terrorism and, as appropriate, to consider establishing integrated mechanisms for meaningful participation of youth in peace processes and dispute resolution.

\section{Resilience: and the Women, Peace, and Security Agenda in Times of Covid-19}

2020 is a significant milestone for gender equality and women's empowerment as it marks the anniversary of unprecedented policy commitments and practical action frameworks. The COVID 19 pandemic has abruptly disrupted plans to assess the progress towards these milestones, celebrate the achievements and set new objectives or goals. ${ }^{2}$

The pandemic has profoundly affected people's lives. Women and girls have been particularly affected by the virus and the measures taken to prevent its spread. Once again, women have shown that they are the backbone of community resilience. The Women, Peace and Security (WPS) movement has shown its strengths, weaknesses, and resilience in this crisis. UN Women also responded

2 Palvina Makan-Lakha and Molly Hamilton, "Resilience and Determination: Women, Peace and Security in the Time of COVID-19," ACCORD (African Centre for the Reconstructive Resolution of Disputes), July 22, 2020, accessed September 17, 2020, https://www.accord.org.za/analysis/resilience-and-determination-women-peaceand-security-in-the-time-of-covid-19/. 
swiftly to the gendered impact of the pandemic. Framing its response, UN Women outlined five priorities: gender-based violence, including domestic violence; social protection and economic stimulus packages to serve women and girls; people support and practical equal sharing of care work; women and girls leading and participating in COVID-19 response planning and decision-making; and data and coordination mechanism to include gender perspectives. ${ }^{3}$

The WPS agenda is relevant in this difficult time. As it was said, women are the backbone of resilient communities, as they themselves are resilient and teach their societies how to face serious challenges. They work with local radio broadcasters to spread messages about the threat of the virus and the appropriate hygiene measures. They educate other women and girls to comply with measures to avoid contracting the virus. In short, they protect their communities. Even in the midst of chaos, women have a powerful voice, and they seek to make their societies more peaceful and resilient.

It is important to apply a feminist lens to the women's peace and security agenda, considering that women are key actors in building resilient democratic societies. Therefore, their rights and voices need to be kept alive and intact. During these uncertain and difficult times, it is pivotal to turn to women leaders from around the world for inspiration. They have forged peace when ravaged by war; they have driven innovation despite all odds; and they persisted in the face of challenges and insisted on building a better future. ${ }^{4}$ Their messages are perseverance, hope, resilience, strength, fight against discrimination, not giving up, and being together.

\section{The Concept of Resilience}

Resilience is a scientific term that applies to materials that have the capacity to return to their original shape after being bent or stretched. Over time, however, the term got to be applied to people as well - people who have the ability to recover readily from illness, depression, defeat, or other kinds of adversity. ${ }^{5}$

Gender is pivotal in this analysis because this article deals with women and because the wider social environments are clearly gendered. Vulnerability and resilience are shaped by gender in various and complex ways. People who suffer marginalization and discrimination are most vulnerable to their negative impact.

It is well documented in the literature how the life-cycle (from infancy to old age) intersects with the different structural vulnerabilities with a particular individual face. Throughout human societies, gender identity dictates a woman's or

3 Makan-Lakha and Hamilton, "Resilience and Determination."

4 "Ten Things You Can Learn from Women's Resilience that Help You Stay Strong in the Time of Covid-19," UN Women, May 19, 2020, accessed September 17, 2020, www.unwomen.org/en/news/stories/2020/5/compilation-ten-things-you-can-learnfrom-womens-resilience.

5 Rose Gantner, "Women and Resilience," in Guide to Good Health (Summer 2012): 7, www.guidetogoodhealth.com/PDF/Archivedlssues/GGH\%20Sum12.pdf. 
man's role in the family and wider society. Other aspects of identity with a profound impact on resilience include ethnicity, race, disability, age, or social status. $^{6}$

For many women, resilience is an instrumental strength. Both women and men need resilience to deal with difficulties in life. But women often need to be more resilient than men to overcome traditional obstacles placed in their way in order to advance in the business world. Too many women, however, are not aware of the amount of resilience they do possess.

Dr. Gail M. Wagnild is the founder of the Resilience Center and an expert on resilience, and she says that when you know your capacity for resilience, it gives you the confidence to deal with whatever life throws at you. Being resilient helps you cope in various ways, be they personal, professional, or social. ${ }^{7}$

Indeed, people do not have control over certain aspects of their lives, such as accidents, natural disasters, and illness, among others, but they have the power to respond to such events and choose to do so with resilience. Themes related to resilience include social connectedness, extending self to others, moving forward with life; curiosity/ever-seeking; "head-on" approach to challenge; "maverick"; and spiritual grounding. ${ }^{8}$

During the past few decades, there has been a proliferation of research on resilience, and the concept has been well-researched in the literature. Yet, in terms of defining resilience, there is controversy in the literature as to whether resilience is a characteristic/personal quality, a process, or an outcome. ${ }^{9}$ In defining resilience as a personal quality, Ahern, Ark, and Byers argue that resilience is an "adaptive stress resistant personal quality," ${ }^{10}$ whereas resilience is defined as "a dynamic process that is influenced by both neural and psychological selforganizations, as well as the transaction between the ecological context and the developing organism." 11 However, when defined as an outcome, resilience is

6 Julie Drolet, Lena Dominelli, Margaret Alston, Robin Ersing, Golam Mathbor, and Hauriu Wu, "Women Rebuilding Lives Post-Disaster: Innovative Community Practices for Building Resilience and Promoting Sustainable Development," Gender \& Development 23, no. 3 (2015): 433-448, quote on p. 438, https://doi.org/10.1080/1355207 4.2015.1096040.

7 Gantner, "Women and Resilience."

8 Beth I. Kinsel, Older Women and Resilience: A Qualitative Study of Adaptation, PhD Dissertation (Columbus, OH: Graduate School, Ohio State University, 2004).

9 Nancy R. Ahern, Pamela Ark, and Jacqueline Byers, "Resilience and Coping Strategies in Adolescents," Paediatric Nursing 20, no. 10 (2008):32-36, https://doi.org/10.7748/ paed2008.12.20.10.32.c6903.

10 Ahern, Ark, and Byers, "Resilience and Coping Strategies in Adolescents," p. 32.

11 W. John Curtis and Dante Cicchetti, "Emotion and Resilience: A Multilevel Investigation of Hemispheric Electroencephalogram Asymmetry and Emotion Regulation in Maltreated and Nonmaltreated Children," Development and Psychopathology 19, no. 3 (2007): 811-840, quote on p. 811, https://doi.org/10.1017/S0954579407000405. 
thought of as "a class of phenomena characterized by good outcomes in spite of serious threats to adaptation or development." 12

It is important to cite different concepts of resilience. According to Ungar "resilience is both the capacity of individuals to navigate their way to the psychological, social, cultural and physical resources that build and sustain their well being and their individual and collective capacity to negotiate for these resources to be provided in culturally meaningful ways." ${ }^{13}$ This understanding of resilience goes beyond an individual notion to a more relational and holistic approach. ${ }^{14}$

Nevertheless, despite the vast range of definitions, there is some agreement in the field to determine if someone is displaying a resilient profile/ resilience. Two elements must be present: namely, adversity (i.e., a high-risk situation or threat) and successful adaptation/competence. ${ }^{15}$ Adversity is evaluated according to negative life circumstances ${ }^{16}$, and adaptation is defined as successful performance on age-developmental tasks. ${ }^{17}$

\section{Women and Resilience}

Women face a variety of advantages and adversities in their lives. They go on realizing a strong investment in and positive orientation toward life regardless of the challenges and losses they experience, particularly in difficult times, such as the one produced by Covid-19. They face common challenges, and there is potential to work with them collectively and to lessen their vulnerability. If they see a need, they respond.

Women can name their experiences, reactions, advantage, and adversity. This means that women are resilient. When are they resilient? When they are faced with many challenges and changes in their lives, such as conflict childhood, unhappy marriages, physical illnesses, the loss of their husbands, to name just a few examples. At present, they make great efforts in order to protect their communities in the face of the pandemic threat. In addition, other political, economic, and social factors impact women. These impacts could not be ignored. For this reason, it is pivotal that women could share their experiences and stories and that they are listened to.

12 Ann S. Masten, "Ordinary Magic: Resilience Processes in Development," American Psychologist 56, no. 3 (2001): 227-238, https://doi.org/10.1037/0003-066X.56.3.227.

13 Michael Ungar, Mehdi Ghazinour, and Jörg Richter, "Annual Research Review: What is Resilience within the Social Ecology of Human Development?," Journal of Child Psychology and Psychiatry 54, no. 4 (2013): 348-366, https://doi.org/10.1111/jcpp.12025. Drolet, et al., "Women Rebuilding Lives Post-Disaster," 435-436.

15 See, for example, Masten, "Ordinary Magic: Resilience Processes in Development."

16 Tammy A. Schilling, "An Examination of Resilience Processes in Context: The Case of Tasha," Urban Review 40, no. 3 (2008): 296-316, https://doi.org/10.1007/s11256-0070080-8.

17 Julie A. Pooley and Lynne Cohen, "Resilience: A Definition in Context," Australian Community Psychologist 22, no. 1 (2010): 30-37, 30-31. 


\section{Examples of Resilience}

\section{Women Suffering Great Trauma}

Many women who are survivors of sexual abuse or assault are very resilient. If they have an environment that contains them, they are more likely to recover from this traumatic experience with profound effects on their lives. They have a sense of hope, the ability to turn a disadvantage into an advantage and transcend adversities in their lives.

These facts affect women and men differently according to the particular gender roles and relations within a specific community. Other aspects of identity make individual women's experiences vary markedly from others. In many countries of the world, women are more likely to be numbered amongst the poor, landless, and malnourished, and these existing vulnerabilities are enhanced when traumatic events happen.

They could see their strengths in painful experiences. In some cases, their faith adds meaning to life. Besides, if they share their experiences of challenge and adversity, they will be empowered to go on and be an example to other women who face the same traumatic experiences.

Optimism, independence, and the ability to overcome obstacles are characteristics of resilient women who consider and acknowledge life as a series of challenges. They also express the belief that one should make plans and not wait for something to happen. This behavior helps them in difficult times and fosters the belief that they could take care of themselves.

Positive or negative events that occur at a particular time in the individual's life can affect resilience development. In the case of girls, if they were resilient in this stage of their lives, they are resilient in their adulthood. The early years of life comprise the beginning of the accumulation of advantage and adversity. From this perspective, persons who overcome adversity early in life attain confidence and self-efficacy from that experience; thus, they accumulate resources that would be available in the event of a subsequent challenge.

In some cases, young girls are particularly vulnerable to being withdrawn from education to assist with the workload, forced child marriages, and trafficking. ${ }^{18}$

The recollection of their experiences reflects their ability to adapt from childhood and influences their longitudinal adaptive coping process. There is recognition of support within their childhood contexts that enabled them to survive, as well as recognition for the individual characteristics they possessed. Understanding these internal characteristics gave them the confidence to find coping strategies as a child but also as an adult. ${ }^{19}$ Women find their own ways of facing

18 Margaret Alston, Women and Climate Change in Bangladesh (London and New York: Routledge, 2015).

19 Pooley and Cohen, "Resilience: A Definition in Context," 33-34. 
adversity, often by being open to risk-taking, creative problem-solving, or joining other women in mutual support.

\section{Refugee and Displaced Women}

Women know about the misery of refugees and the fate of those who were displaced.

\section{- Activist Safaa Elagib Adam, Sudan/Darfour 20}

Resilience is applied to refugees since they have experienced major life upheavals and frequently attempt to rebuild individual, family, and the whole of community trajectories. ${ }^{21}$ The same is applied to displaced women.

It is very important to apply the resilience 'lens' to understand the experience of refugee and displaced women, who in general, are single mothers and have to face many difficulties, which increases their vulnerability. Several studies established that within the category of internally displaced people (IDP), women are the vulnerable within the vulnerable. They face and resist all types of shocks, for example, conflict and natural disaster, among others. The aforementioned studies account for displacement-related vulnerabilities such as access to employment, housing, land and property, and food and highlight higher poverty rates of urban IDPs than the rest of the urban poor. ${ }^{22}$ Refugee and displaced women put their children's welfare in the first place to provide them with better opportunities in the social, cultural, linguistic, economic, and political environment.

From the standpoint of privileged "first world" lives, the question of exploring the wellbeing of refugee women is in danger of being reduced to a simplistic dichotomy of either pathologizing in relation to trauma or valorizing with regard to resilience. ${ }^{23}$

We emphasize these matters within the context of managing everyday life, where the daily routine is not simply the vessel in which lives are lived; rather, it is the milieu in which the social processes of resilience are continuously enacted. The women's resilience embedded in daily routines challenges the focus of much of the resilience discourse on 'extraordinary' events, while the social dimension of resilience is situated in person-environment interactions acknowledges resilience as an ongoing process achieved over time and, according to contexts, rather than an atypical static inner trait.

20 No Women - No Peace, 17.

21 Caroline Lenette, Mark Brough, and Leoni Cox, "Everyday Resilience: Narratives of Single Refugee Women with Children," Qualitative Social Work 12, no. 5 (2013): 637653.

22 Nassim Majidi and Camille Hennion, "Resilience in Displacement? Building the Potential of Afghan Displaced Women," Journal of Internal Displacement 4, no. 1 (January 2014): 78-91.

23 Lenette, Brough, and Cox, "Everyday Resilience," 638. 
Despite the fact that many refugee women are isolated and experience significant emotional, financial, and physical risks post-resettlement, they show strengths in their daily lives. Regarding IDP women, the concept of resilience has been increasingly used to describe their abilities to adapt to new environments after the shock of displacement, based on the development of specific coping mechanisms.

\section{Be Resilient in Times of Covid-19}

Having come through this pandemic hardship contributes to women's feelings of self-worth and control. When women share their struggles, they teach how they have managed, talking heart-to-heart about their concerns. Dialogue and sharing of experience are important indicators of building resilience and can be applied to the pandemic.

COVID-19 has shown that women have the capacity to gain social competence, the capacity to be flexible, empathetic, and have the ability to plan and think critically and reflectively. Women are rebuilding their lives in the middle of this complex event and promoting sustainable development. Women perfectly know that building resilience requires more than reducing vulnerability. It needs empowering responses to disasters and trauma, which aim to support and foster women's resilience, enhancing their ability to answer to traumatic episodes.

It is pivotal that governments increase resilience capacity by focusing on women (the protagonists of this article) and link this to the Sustainable Development Goals, in which they are engaged. While the vulnerabilities of women in difficult times, as the one humanity is facing at present because of the pandemic, are evident, so too is their resilience. It is important to acknowledge women's capacities to care for their children and family members while, depending upon the social context, women are engaged in multiple activities and tasks in the productive, reproductive, and community spheres.

The need to address the diverse challenges women face is integral to a more holistic approach to building resilience and sustainable development in communities that are devastated. This pandemic shows that resilience empowers women, ceasing to be a silent group in the community, which has a profound effect in their visions about right, justice, and human dignity. Their skills and leadership are instrumental in order to build resilience. It is fundamental that international agreements must promote gender equality and human rights to build the resilience of women and girls in their communities. The Pandemic confronts women and all humanity with the need to promote a sense of purpose, perseverance, equanimity, balance, and self-reliance.

\section{Conclusion}

As we could appreciate in the present article, some important considerations as regards resilience begin to emerge. Certain pivotal internal resources contribute to resilience such as self-efficacy, coping, and sense of belonging. After studying 
the subject in-depth, resilience represents the interaction between risk factors (vulnerability) and protective resources (protection). Resilience is built from the foundation of economic and social security. Living in poverty as part of a marginalized group creates few opportunities to build up the resources needed to fall back on at a time of disaster. Social protection initiatives that provide access to essential services and income, including protection from the risks of disasters, are a universal human right and contribute to building resilience by improving economic security, health, and wellbeing. ${ }^{24}$

Without any doubt, women are actors of change since they cope with different strategies. Resilience is a key factor for women who has experienced traumatic events in their lives. They give us the following message: "Believe and trust in yourself."

Two final considerations, taking into account that much more remains to be done. As Eleanor Roosevelt, former US Delegate to the United Nations, said: "We call on the governments of the world to encourage women everywhere to take a more conscious part in national and international affairs, and on women to come forward and share in the work of peace and reconstruction as they did in the war and resistance." These words apply more than ever to the moment humanity goes through due to COVID-19. Resilience is that wound through which the light enters and which becomes present after having faced adverse facts.

\section{Disclaimer}

The views expressed are solely those of the author and do not represent official views of the PfP Consortium of Defense Academies and Security Studies Institutes, participating organizations, or the Consortium's editors.

\section{About the Author}

María Julia Moreyra is an Argentinian Lawyer. She holds a Master's Degree in International Relations (FLACSO, Argentina). At present, she is a Member of the Ministry of Women, Gender Policies and Sexual Diversity of the Province of Buenos Aires, Argentina. Since 2009 she is Regional Coordinator for Latin America and the Caribbean of the Swiss organization PeaceWomen Across the Globe (PWAG). Ms. Moreyra is Peace Fellow 2016 (Rotary Peace Center, Chulalongkorn University, Thailand), Activator of Positive Peace (Latin America), and Ambassador of the Institute of Economics and Peace (Sidney, Australia). She is a trainer of the Course "Prevention of Human Trafficking with Sexual Purposes," aimed to high-school teachers in Uruguay, invited by the Rotary Club of Montevideo due to her expertise on the topic. She has specialized in "Women, Peace and Security," is a regular speaker at national and international conferences with a number of published books and articles in the areas of her specialty.

E-mail: mujeresdepazenelmundo@gmail.com

24 Drolet, et al., "Women Rebuilding Lives Post-Disaster," 445. 


\section{Acknowledgment}

Connections: The Quarterly Journal, Vol. 19, 2020 is supported by the United States government. 